\title{
Effect of high-dose methylprednisolone therapy on phagocyte function in systemic lupus erythematosus
}

\author{
S. H. BOGHOSSIAN, ${ }^{1}$ D. A. ISENBERG ${ }^{2} \mathrm{G} . \mathrm{WRIGHT}^{3} \mathrm{M} \cdot \mathrm{L} . \mathrm{SNAITH},{ }^{2}$ AND
} A. W. SEGAL

From the Departments of ${ }^{1}$ Haematology and ${ }^{2}$ Rheumatology, and the ${ }^{3}$ Faculty of Clinical Sciences and Computer Center, University College London, Gower Street, London WCI

SUMmARY Circulating phagocytes play a major role in the defence of the host against microbial infection. In an attempt to identify the reason for the unusual susceptibility to infection of patients with systemic lupus erythematosus (SLE) various parameters of phagocytic cell function were assessed kinetically in whole blood, and the accumulation of cells in areas of inflammation was studied in vivo with the skin window technique. The effect on these parameters of conventional therapy with glucocorticoids and pulse therapy with large doses of methylprednisolone were examined. Patients on conventional doses of steroids had no abnormality of phagocyte function that might have predisposed to infection, apart from a reduced accumulation of monocytes in areas of inflammation and decreased lactoferrin secretion. Pulse therapy with methylprednisolone considerably delayed the secretion of lactoferrin and the adherence of neutrophils in most of the patients, as well as impairing bacterial killing and digestion.

Patients with systemic lupus erythematosus (SLE) - are predisposed to serious infection. ${ }^{12}$ Steroid therapy is also associated with an increased susceptibility to infection through an unknown mechanism. ${ }^{34}$ In an attempt to optimise the antiinflammatory effects while reducing the side effects a regimen of steroid treatment has been developed in which large doses of drug are administered by intravenous 'bolus' infusion. ${ }^{5} 6$ This has been shown to a have a beneficial effect on patients with $\operatorname{SLE}^{78}$ and to produce less severe suppression of the circulating lymphocytes than conventional oral doses of glucocorticoids. ${ }^{6}$

New techniques have recently been developed for the investigation of phagocyte function. ${ }^{910} \mathrm{We}$ used them to investigate patients with SLE, both before and after treatment with conventional doses of glucocorticoids and methylprednisolone pulse therapy (MPPT), in the hope that they might identify some hitherto undescribed defect in these patients.

Accepted for publication 24 February 1984.

Correspondence to Dr A. W. Segal, Department of Haematology, Faculty of Clinical Sciences, University College London, University Street, London WC1.

\section{Patients and methods}

Twenty-four patients with active SLE who fulfilled four or more of the criteria of the revised American Rheumatism Association criteria for classification of the disease ${ }^{11}$ were studied. All were female aged between 22 and 59 years (mean 26). Disease activity was graded as severely active, moderately active, or inactive at the time of study according to a described classification. $^{12}$

The effect of MPPT ( $1 \mathrm{~g}$ of sodium succinate salt in $500 \mathrm{ml}$ of saline intravenously over four hours on each of three successive days) on a wide range of phagocyte functions was tested on 15 patients on maintenance therapy with relatively small doses of prednisolone $(5-15 \mathrm{mg} / \mathrm{day})$. Six were studied with the perfusion chamber, skin windows were performed on four, and both techniques were used in the remaining five. Control studies on the perfusion chamber and skin window technique were performed on 18 healthy subjects matched for age (mean $\pm S D, 24 \pm 5$ years) and sex.

The kinetics of lactoferrin secretion were determined in the perfusion chamber in four patients on maintenance doses of prednisolone of $20-40 \mathrm{mg}$-day before and after MPPT, in five patients with active 
disease who did not receive any glucocorticoid therapy, and five normal subjects matched for age and sex.

\section{PHAGOCYTE FUNCTION}

In vitro. The kinetic measurements of phagocyte function in whole blood were performed by the perfusion chamber technique. ${ }^{9}$ This measures the clearance from blood by adherence to glass of neutrophils, monocytes, and platelets and the clearance (phagocytosis) and digestion of ${ }^{14} \mathrm{C}$-protein labelled Staphylococcus aureus and ${ }^{3} \mathrm{H}$-glucose labelled Streptococcus pneumoniae simultaneously in whole blood. The secretion of lactoferrin by neutrophils and killing of Staph. aureus are also determined.

In vivo. Neutrophil and monocyte infiltration into skin abrasions and their rate of migration into superimposed membranes were measured as described by Addison et al. ${ }^{10}$

In patients receiving MPPT the studies were performed immediately before treatment and 24 hours after the completion of the last dose.

Statistical analysis. The data derived previously by the perfusion chamber technique were analysed as described previously. ${ }^{9}$ Pre- and post-MPPT values were compared with those from healthy subjects by Student's unpaired $t$ test, and with each other by paired $t$ analysis; the $95 \%$ confidence limit was considered to be significant.

The rates of lactoferrin secretion were analysed by comparing the slopes and intercepts of the regression lines derived from the calculated curve fitting programme. ${ }^{13}$

\section{Results}

\section{PHAGOCYTE FUNCTION IN VITRO}

Cell clearance. The mean clearance rates of total leucocytes, neutrophils, monocytes, and platelets in patients with SLE, before MPPT, were slightly higher than normal (Table 1). MPPT caused a significant reduction in the rate $(\mathrm{p}<0.05)$ and extent $(\mathrm{p}<0.025)$ of neutrophil clearance (Fig. 1, Table 1).

MPPT caused a significant increase in the numbers of neutrophils $(4 \cdot 2 \pm 0.5$ (mean \pm SD) to $\left.10 \cdot 0 \pm 1 \cdot 0 \times 10^{9} / 1\right)$ and platelet $(2 \cdot 3 \pm 0 \cdot 1$ to $\left.3 \cdot 0 \pm 0 \cdot 1 \times 10^{9} / 1\right)$ but did not result in significant changes in the numbers of the other blood cells. However, these changes in cell numbers were not related to the rate and the extent of clearance of the different cell types in whole blood, either before or after MPPT.

Bacterial clearance. The rate of clearance of Str. pneumoniae was slightly lower than normal in the patients with SLE on conventional doses of steroids (Table 2). After MPPT the rate of clearance of this organism was enhanced in eight patients and decreased in one (Fig. 2a, Table 2). The extent of clearance at 16 min was also increased after MPPT $(\mathrm{p}<0.025$; Fig. 2b, Table 2).

The rates of clearance of Staph. aureus in patients with SLE were significantly higher than in normal subjects (Table 2). In the majority of patients MPPT caused a further increase in this clearance rate, as well as the proportion of bacteria cleared at 16 min (Fig. 2c and d, Table 2). In three patients the clearance of these organisms was reduced by MPPT.

Table 1 Cell clearance in patients with systemic lupus erythematosus

\begin{tabular}{|c|c|c|c|c|c|c|c|c|}
\hline \multirow[b]{2}{*}{ Subjects } & \multicolumn{2}{|c|}{ Leucocytes } & \multicolumn{2}{|c|}{ Neutrophils } & \multicolumn{2}{|c|}{ Monocytes } & \multicolumn{2}{|l|}{ Platelets } \\
\hline & Rate & Extent & Rate & Extent & Rate & Extent & Rate & Extent \\
\hline $\begin{array}{l}\text { Control } \\
n\end{array}$ & $\begin{array}{l}4 \cdot 2 \pm 2 \cdot 0 \\
18\end{array}$ & $\begin{array}{l}45 \cdot 0 \pm 14 \cdot 1 \\
18\end{array}$ & $\begin{array}{l}7 \cdot 1 \pm 3 \cdot 4 \\
18\end{array}$ & $\begin{array}{l}58 \cdot 5 \pm 15 \cdot 2 \\
18\end{array}$ & $\begin{array}{l}6 \cdot 6 \pm 4 \cdot 4 \\
9\end{array}$ & $\begin{array}{l}59 \cdot 2 \pm 21 \cdot 6 \\
9\end{array}$ & $\begin{array}{l}2 \cdot 4 \pm 0 \cdot 7 \\
12\end{array}$ & $\begin{array}{l}29 \cdot 4 \pm 6 \cdot 6 \\
12\end{array}$ \\
\hline $\begin{array}{l}\text { SLE (pre-MPPT) } \\
n \\
\text { p }\end{array}$ & $\begin{array}{l}5 \cdot 7 \pm 2 \cdot 6 \\
11\end{array}$ & $\begin{array}{l}51 \cdot 0 \pm 16 \cdot 1 \\
11\end{array}$ & $\begin{array}{l}9 \cdot 6 \pm 3 \cdot 4 \\
11 \\
<0.05\end{array}$ & $\begin{array}{l}67 \cdot 4 \pm 14 \cdot 7 \\
11\end{array}$ & $\begin{array}{l}11 \cdot 8 \pm 7 \cdot 3 \\
5\end{array}$ & $\begin{array}{l}72 \cdot 9 \pm 15 \cdot 6 \\
5\end{array}$ & $\begin{array}{l}5 \cdot 7 \pm 3 \cdot 6 \\
4\end{array}$ & $\begin{array}{l}51 \cdot 9 \pm 20 \cdot 0 \\
4\end{array}$ \\
\hline $\begin{array}{l}\text { SLE (post-MPPT) } \\
\text { n } \\
\text { p } \\
\text { p }^{*}\end{array}$ & $\begin{array}{l}5 \cdot 5 \pm 2 \cdot 6 \\
11\end{array}$ & $\begin{array}{l}46 \cdot 3 \pm 18 \cdot 9 \\
11\end{array}$ & $\begin{array}{l}6 \cdot 2 \pm 2 \cdot 9 \\
11 \\
<0.05\end{array}$ & $\begin{array}{l}49 \cdot 9 \pm 20 \cdot 1 \\
11 \\
<0 \cdot 025\end{array}$ & $\begin{array}{l}13 \cdot 8 \pm 2 \cdot 9 \\
5 \\
<0 \cdot 005\end{array}$ & $\begin{array}{l}82 \cdot 2 \pm 9 \cdot 9 \\
5 \\
<0 \cdot 025\end{array}$ & $\begin{array}{l}5 \cdot 9 \pm 3 \cdot 9 \\
4\end{array}$ & $\begin{array}{l}46 \cdot 3 \pm 22 \cdot 1 \\
4\end{array}$ \\
\hline
\end{tabular}

Fractional clearance rate (\% cleared every $5 \mathrm{~min})$ and extent $(\%$ cleared at $60 \mathrm{~min})$ of total leucocytes, neutrophils, monocytes, and platelets in patients with SLE before (pre) and after (post) MPPT, compared with healthy subjects (controls). Values were derived from a computerised curve fitting program. ${ }^{14}$ Results are expressed as the mean \pm 1 SD. The level of the differences between the healthy subjects and patients in each phase of treatment (p), and between groups of patients before and after MPPT $\left(\mathrm{p}^{*}\right)$ is indicated where statistically significant.

$\mathbf{n}=$ Number of subjects in each group. 


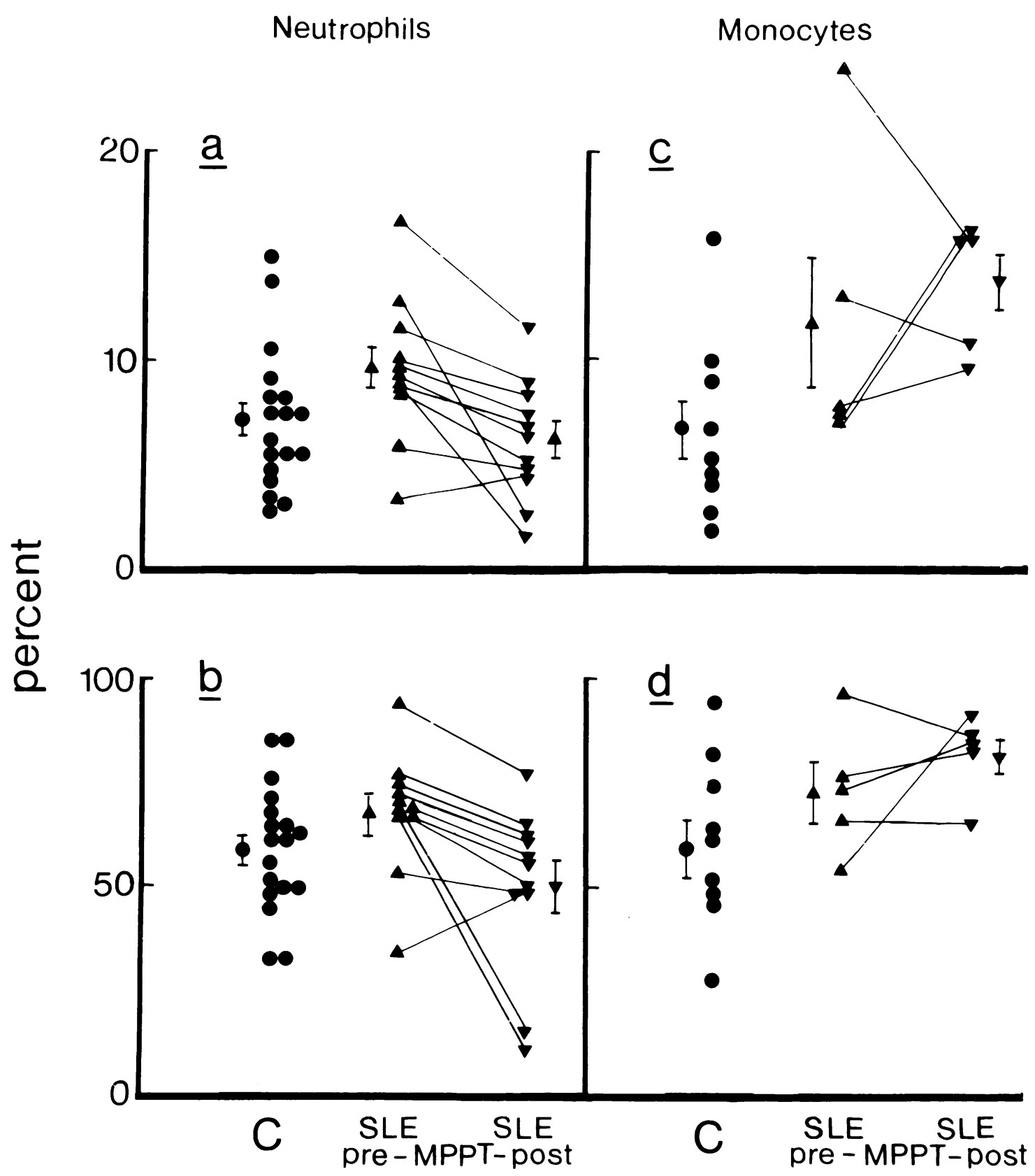

Fig. 1 The rate and extent of clearance of neutrophils $(\mathrm{a}, \mathrm{b})$ and monocytes $(\mathrm{c}, \mathrm{d})$ in healthy subjects $(\mathrm{c}, \boldsymbol{\bigcirc})$ and patients with SLE, before $(\Delta)$ and after $(\nabla)$ MPPT. Results are expressed as the percentage of neutrophils and monocytes cleared every $5 \mathrm{~min}(\mathrm{a}, \mathrm{c})$ and the percentage of cleared cells at time $60 \mathrm{~min}(\mathrm{~b}, \mathrm{~d})$. Mean \pm SE of each group is also shown (市). See Table I for absolute values and statistical significance of differences between groups. 
544 Boghossian, Isenberg, Wright, Snaith, Segal

Table 2 Bacterial clearance and solubilisation in patients with systemic lupus erythematosus

\begin{tabular}{|c|c|c|c|c|c|c|c|c|}
\hline \multirow[b]{2}{*}{ Subjects } & \multicolumn{2}{|c|}{$\begin{array}{l}\text { Streptococcus pneumoniae } \\
\text { Clearance }\end{array}$} & \multicolumn{2}{|c|}{ Solubilisation } & \multicolumn{2}{|c|}{$\begin{array}{l}\text { Staphylococcus aureus } \\
\text { Clearance }\end{array}$} & \multicolumn{2}{|c|}{ Solubilisation } \\
\hline & Rate & Extent & Rate & Extent & Rate & Extent & Rate & Extent \\
\hline $\begin{array}{l}\text { Control } \\
\mathrm{n}\end{array}$ & $\begin{array}{l}9 \cdot 7 \pm \cdot 7 \\
13\end{array}$ & $\begin{array}{l}28 \cdot 6 \pm 25 \cdot 3 \\
13\end{array}$ & $\begin{array}{l}1 \cdot 9 \pm 0 \cdot 8 \\
13\end{array}$ & $\begin{array}{l}16 \cdot 6 \pm 7 \cdot 2 \\
13\end{array}$ & $\begin{array}{l}12 \cdot 0 \pm 6 \cdot 0 \\
13\end{array}$ & $\begin{array}{l}58 \cdot 4 \pm 13 \cdot 9 \\
13\end{array}$ & $\begin{array}{l}0 \cdot 52 \pm 0 \cdot 34 \\
13\end{array}$ & $\begin{array}{l}6 \cdot 7 \pm 3 \cdot 4 \\
13\end{array}$ \\
\hline $\begin{array}{l}\text { SLE (pre-MPPT) } \\
\text { n } \\
\text { p }\end{array}$ & $\begin{array}{l}7 \cdot 5 \pm 6 \cdot 4 \\
9\end{array}$ & $\begin{array}{l}22 \cdot 5 \pm 21 \cdot 9 \\
9\end{array}$ & $\begin{array}{l}1 \cdot 8 \pm 0 \cdot 9 \\
9\end{array}$ & $\begin{array}{l}15 \cdot 6 \pm 7 \cdot 5 \\
9\end{array}$ & $\begin{array}{l}18 \cdot 8 \pm 7 \cdot 8 \\
11 \\
<0 \cdot 0125\end{array}$ & $\begin{array}{l}56 \cdot 7 \pm 14 \cdot 7 \\
11\end{array}$ & $\begin{array}{l}0 \cdot 94 \pm 0 \cdot 81 \\
11\end{array}$ & $\begin{array}{l}10 \cdot 6 \pm 7 \cdot 6 \\
11\end{array}$ \\
\hline $\begin{array}{l}\text { SLE (post-MPPT) } \\
\text { n } \\
\text { p } \\
\text { p }^{*}\end{array}$ & $\begin{array}{l}14 \cdot 5 \pm 11 \cdot 3 \\
9 \\
<0.05\end{array}$ & $\begin{array}{l}34 \cdot 2 \pm 29 \cdot 2 \\
9 \\
<0.025\end{array}$ & $\begin{array}{l}1 \cdot 4 \pm 0 \cdot 7 \\
9 \\
<0.01\end{array}$ & $\begin{array}{l}13 \cdot 5 \pm 5 \cdot 8 \\
9 \\
<0 \cdot 05\end{array}$ & $\begin{array}{l}22 \cdot 8 \pm 5 \cdot 2 \\
11 \\
<0 \cdot 0005 \\
<0 \cdot 05\end{array}$ & $\begin{array}{l}71 \cdot 4 \pm 15 \cdot 9 \\
11 \\
<0 \cdot 025 \\
<0 \cdot 025\end{array}$ & $\begin{array}{l}0 \cdot 38 \pm 0 \cdot 27 \\
11\end{array}$ & $\begin{array}{l}5 \cdot 1 \pm 3 \cdot 4 \\
11\end{array}$ \\
\hline
\end{tabular}

The clearance and solubilisation of Str. pneumoniae and Staph. aureus from the blood of patients with SLE, before (pre) and after (post) MPPT, compared with healthy subjects (control). The rate of clearance is expressed as the percentage of bacteria cleared every $5 \mathrm{~min}$ and solubilisation as the percentage solubilised in relation to the square root of the increase in time in minutes. The extent of clearance and solubilisation is expressed as the percentage cleared or solubilised after 16 and 120 minutes respectively. Values were derived from a computerised curve fitting program. Results are expressed as the mean \pm 1 SD. The level of the differences between healthy subjects and patients in each treatment group ( $p$ ) and between patients before and after MPPT ( $\left.p^{*}\right)$ is indicated where statistically significant.

$\mathbf{n}=$ Number of subjects in each group.

Although the blood neutrophil count was significantly higher in patients after treatment, there was no correlation between the total or differential cell count and the rate or extent of clearance of staphylococci or pneumococci.

Bacterial solubilisation. The patterns of solubilisation of the glucose label of Str. pneumoniae and the protein label of Staph. aureus in patients were similar to those in normal subjects (Fig. 3a). MPPT caused a significant reduction in the rate and extent of solubilisation of the glucose label (Fig. 3a, Table 2).

The solubilisation of the protein of Staph. aureus was slightly greater than normal in the patients before MPPT. All except one showed a reduction in the rate of release of solubilised protein after MPPT $(\mathrm{p}<0.01$, Fig. 3c). The extent of solubilisation of Staph. aureus was also significantly lower after MPPT ( $<<0.005$; Fig. 3d, Table 2).

No correlation was observed between the clearance of these two bacteria and the rate and the extent of solubilisation. Solubilisation was also unrelated to the original blood cell counts and the rate and extent of clearance of the different cell types.

Bacterial killing. The number of residual viable intracellular Staph. aureus was normal in patients with SLE on conventional steroid therapy. After MPPT significantly more viable organisms remained in comparison with the pretreatment state $(p<0.05)$ and healthy subjects $(\mathrm{p}<0 \cdot 01$; Fig. 4$)$. In healthy subjects the number of colonies did not correlate with the rate and extent of clearance of neutrophils or monocytes, or the rate and extent of clearance of staphylococci.

Lactoferrin secretion. The rate of secretion was linear with time in normal subjects. In the patients not receiving any steroid therapy the pattern of release was similar to that of healthy subjects at the earlier times and was slightly delayed at about one hour (Fig. 5a). Secretion was significantly delayed in the patients treated with steroids $(\mathrm{p}<0.05)$ and was not significantly changed by subsequent MPPT (Fig. 5a).

When the rate of secretion was corrected for the number of adherent neutrophils (because it is the adherence to glass that stimulates release), it was found to be normal in patients not on steroids, markedly depressed in the subjects on maintenance treatment with steroids $(\mathrm{p}<0.0001)$, and even further depressed by MPPT $(p<0 \cdot 001$; Fig. $5 b)$.

The concentrations of lactoferrin in unstimulated neutrophils purified from the untreated patients $\left(1.8 \pm 0.3 \mu \mathrm{g} / 10^{6}\right.$ cells, mean $\left.\pm \mathrm{SE}\right)$, and those on maintenance doses of steroid $\left(1.7 \pm 0.6 \mu \mathrm{g} / 10^{6}\right.$ cells) was similar to those in control cells $\left(1.75 \pm 0.4 \mu \mathrm{g} / 10^{6}\right.$ cells). After MPPT the cellular concentrations of lactoferrin was slightly decreased $\left(1 \cdot 0 \pm 0 \cdot 1 \mu \mathrm{g} / 10^{6}\right.$ cells $)$. This reduction was not sufficient to explain the very delayed secretion of 


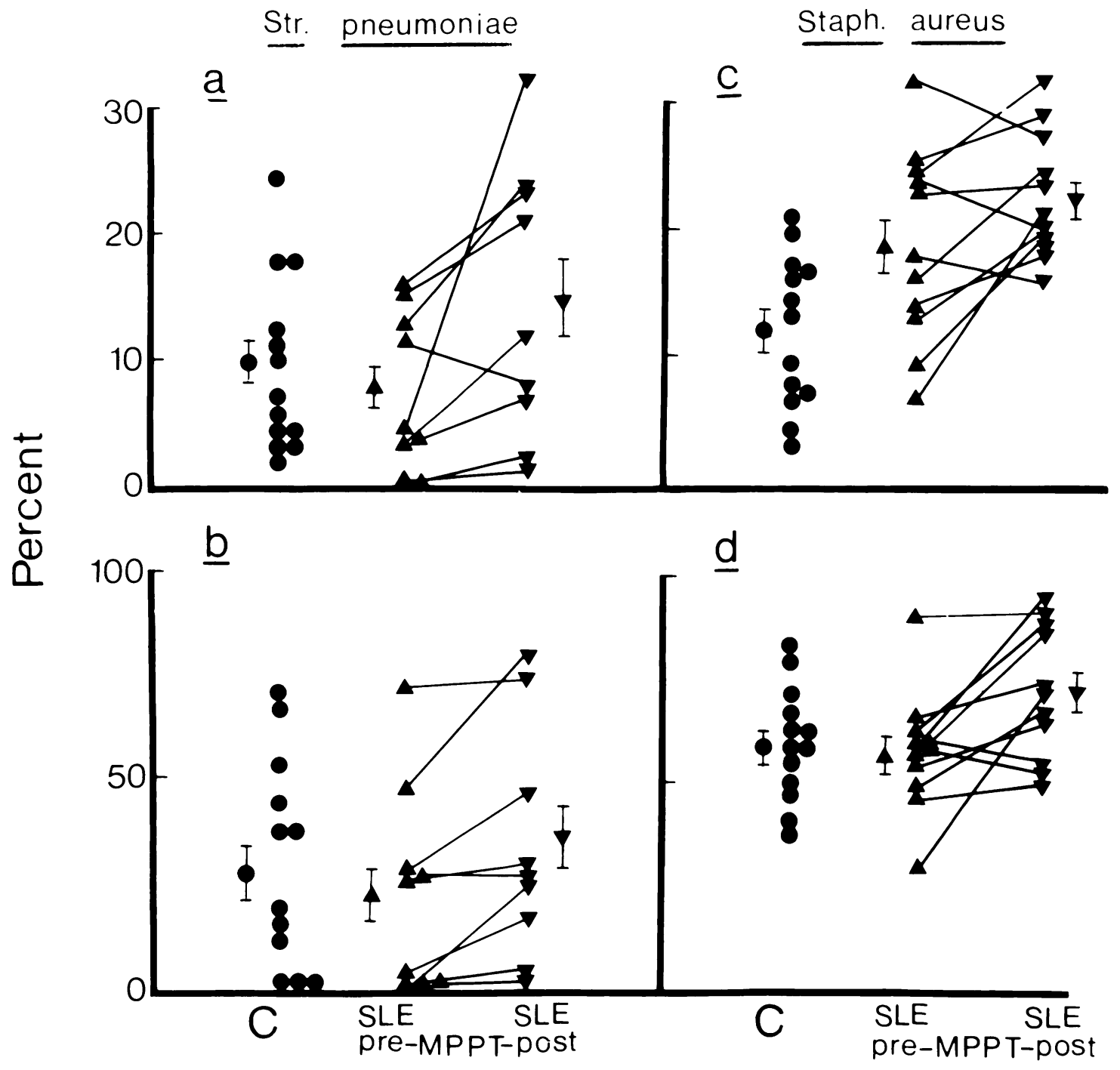

Fig. 2 The rate and extent of the clearance of Str. pneumoniae (a, b) and Staph. aureus (c, d) in healthy subjects (c, 0$)$ and in patients with $S L E$, before $(\Delta)$ and after $(\boldsymbol{\nabla})$ MPPT. Results are expressed as a percentage of Str. pneumoniae and Staph. aureus cleared every 5 min (a, c) and the percentage of bacteria cleared at 16 min (b, d) Mean $\pm S E$ are also shown (I). See Table 2 for absolute values and statistical significance of differences between groups.

lactoferrin by the cells of these patients. The concentration of lactoferrin in the original plasma samples was similar in the four groups.

\section{CELL MOVEMENT FROM SKIN WINDOWS}

A crude visual estimation of the density of neutrophils infiltrating the membranes did not reveal any obvious differences between the normal subjects and patients on maintenance doses of steroids. The rate of movement of neutrophils into the membranes was normal in the patients before MPPT, after which it was significantly delayed (Fig. 6a).

Non-specific esterase (NSE) ${ }^{15}$ positive mononuclear phagocytes were undetectable in the skin window exudates of seven of the nine patients on conventional steroid therapy. After MPPT, NSE positive cells reappeared in two of these seven patients, in whom they accounted for about $5 \%$ of 


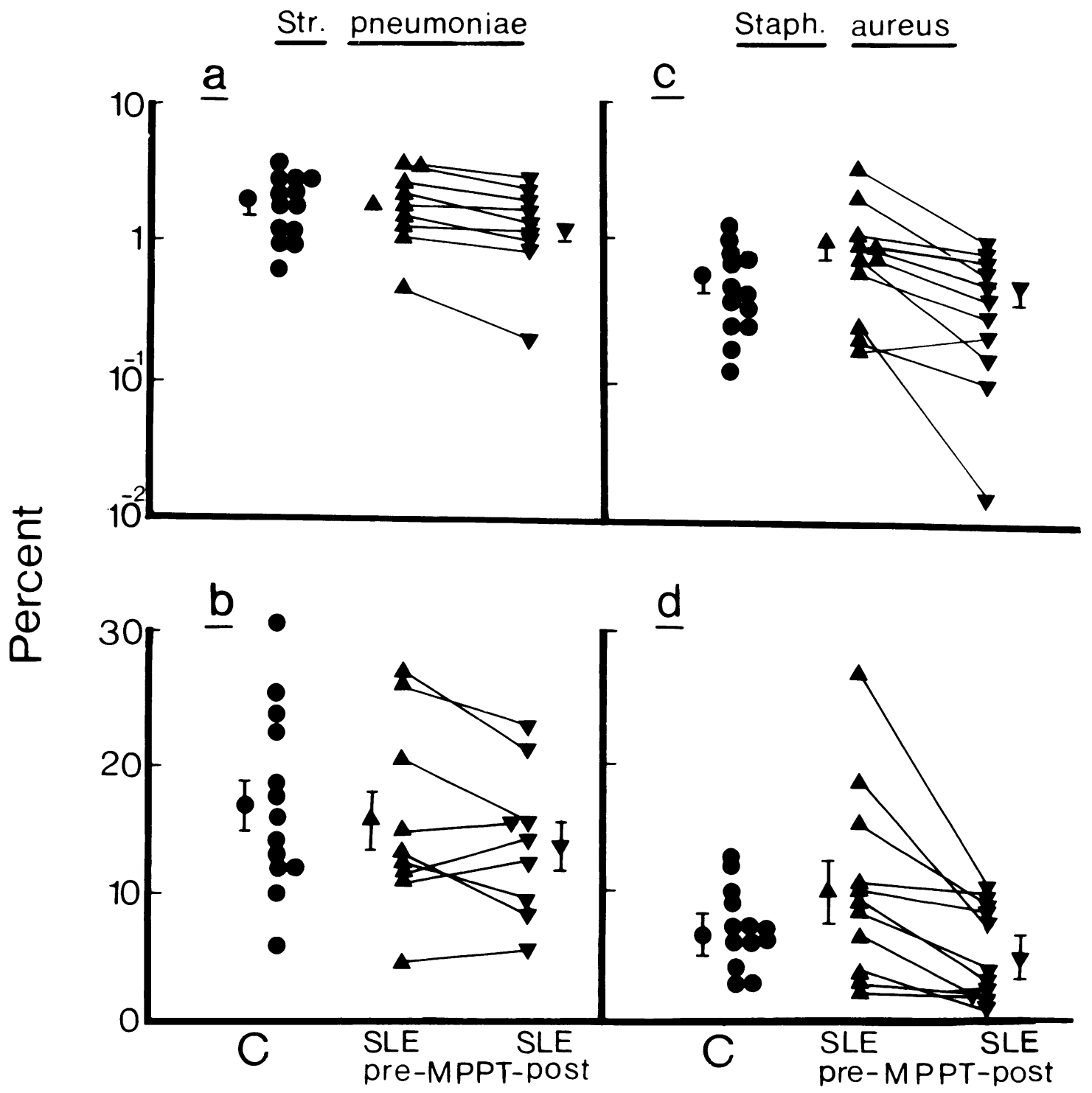

Fig. 3 The rate and extent of the solubilisation of Str. pneumoniae labelled with ${ }^{3} \mathrm{H}$-glucose $(\mathrm{a}, \mathrm{b})$ and Staph. aureus labelled with ${ }^{14} \mathrm{C}$-protein hydrolysate $(\mathrm{c}, \mathrm{d})$ in healthy subjects $(\mathrm{c}, \bigcirc)$ and in patients with $S L E$, before $(\mathbf{\Delta})$ and after $(\nabla)$ MPPT. Results are expressed as a percentage of bacterial radioactivity released in relation to the square root of the time (a, c) and the percentage solubilised at $120 \mathrm{~min}(\mathrm{~b}, \mathrm{~d})$. Mean $\pm S E$ is also shown (市). See Table 2 for absolute values and statistical significance of differences between groups. 


\section{Total}

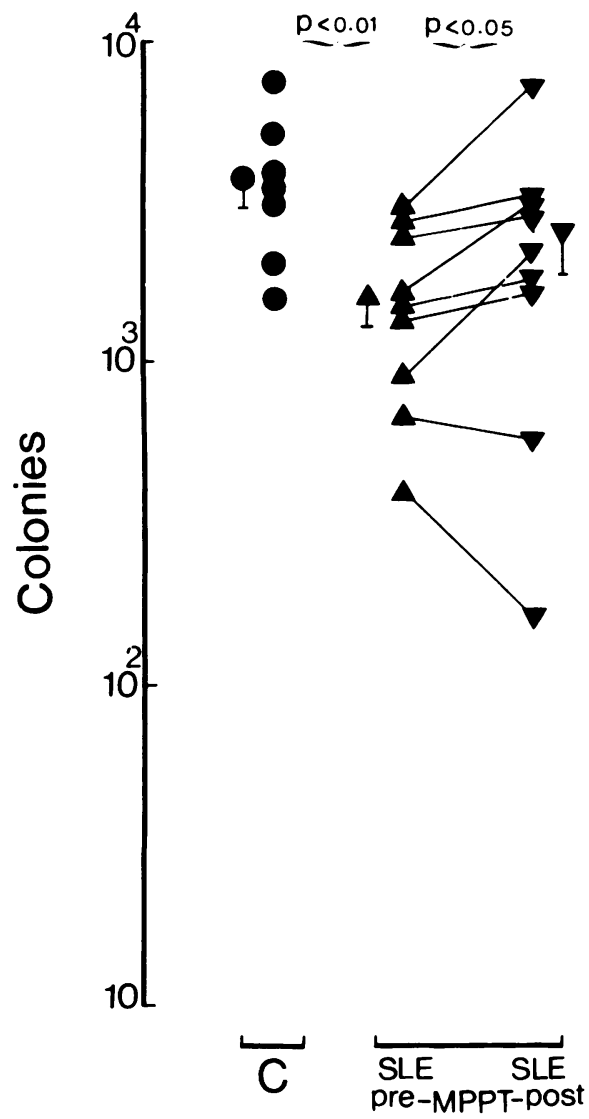

\section{Lysostaphin}

Fig. 4 Bacterial killing in patients with SLE before ( $\mathbf{\Delta})$ and after $(\boldsymbol{\nabla})$ $M P P T$ in comparison with healthy subjects $(\mathrm{c}, \mathrm{O})$. Residual viable bacteria on coverslips before (total) and after (lysostaphin) lysis of extracellular organisms by lysostaphin. Results are expressed as the number of bacteria per coverslip surface. Mean $\pm S E$ of each group is also shown (甲). the exudate cells (Fig. 6c). In the two cases in which NSE positive phagocytes were originally detected in the exudate MPPT was followed by no change in one and an increase in the proportion of these cells from $8 \%$ to $30 \%$ in the other (Fig. $6 \mathrm{c}$ ).

No relationship was discovered between neutrophil and monocyte migration into the skin windows and their original blood counts or rates of clearance in the chamber.

\section{Discussion}

These studies failed to demonstrate an obvious impairment of the antimicrobial functions of phagocytes in patients with SLE on maintenance doses of steroids, apart from the failure of accumulation of monocytes in skin window exudates. Maintenance doses of steroids impaired the secretion of lac- toferrin, and bolus therapy influenced a variety of other functions.

The normal adherence of leucocytes to glass and the migration of neutrophils in vivo in patients receiving small doses of steroids confirms previous studies on purified cells ${ }^{16} 17$ but contrasts with the qualitative skin window studies of Gewurz et al. ${ }^{18}$ The failure of the monocytes of these patients to accumulate normally at sites of acute inflammation could be related to an inadequate production of appropriate mediators or some impairment in the response of these cells, possibly as a result of their interaction with immune complexes. ${ }^{19}$

MPPT significantly reduced the rate of adherence of neutrophils to glass. A similar observation has been made on purified neutrophils separated from the blood of SLE patients two hours after MPPT. ${ }^{17}$ MPPT also reduced neutrophil migration from skin 

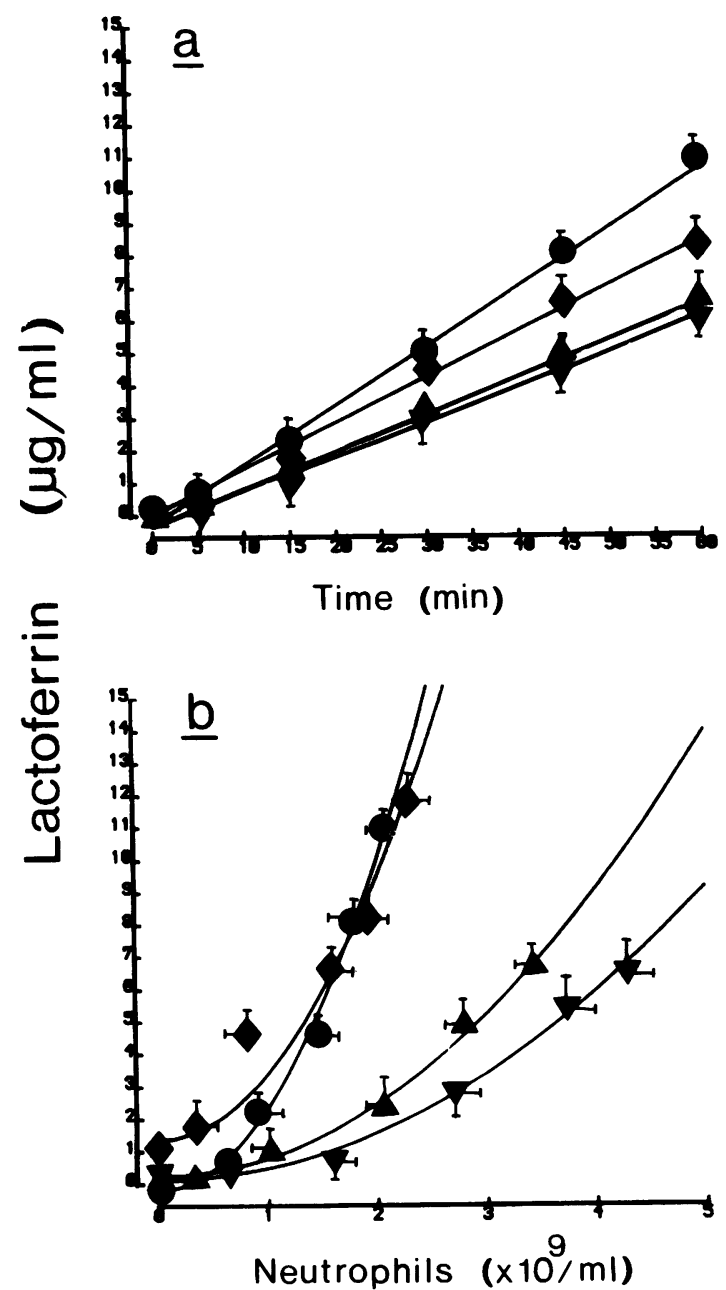

Fig. 5 Lactoferrin secretion: (a) absolute rate, and (b) corrected for the numbers of adherent neutrophils, in untreated patients $(\$)$, those on maintenance doses of prednisolone ( $\mathbf{\Delta})$, and subsequently after MPPT ( $\mathbf{V})$ compared with healthy subjects $(\bigcirc)$. Mean $\pm S E$ of each group is also shown ( $\longrightarrow$ ).

windows. Because these cells migrate normally in chemotactic chambers, ${ }^{17}$ this suggests that the MPPT might affect the afferent limb of the inflammatory response such as the local release of inflammatory mediators and the response of the microvasculture.

The clearance of both Staph. aureus and Str. pneumoniae was significantly increased in the patients after they received MPPT. By contrast Hällgren and associates ${ }^{20}$ found phagocytosis to be reduced after $1 \mathrm{~g}$ methylprednisolone therapy. However, they studied purified cells where the drug may have been removed by the isolation procedure or some other technical difference.

The killing of Staph. aureus was reduced in patients with SLE after MPPT. As the generation of superoxide radicals by the neutrophils of SLE patients after MPPT is normal, ${ }^{17}$ the impaired killing may be due to interference with the nonoxygen-dependent microbicidal system. Steroids might protect the microbe by impairing the release of granule enzymes into the phagocytic vacuole, possibly through an effect on their membranes. ${ }^{21}$ Impaired release of digestive proteins could also explain the reduction in the solubilisation of both Staph. aureus and Str. pneumoniae observed after MPPT.

Lactoferrin, which is secreted exclusively by neutrophils, ${ }^{22}$ is released into the plasma on cell adherence. Secretion was normal in untreated patients with SLE, delayed in those patients receiving relatively high $(20-40 \mathrm{mg} /$ day $)$ maintenance doses of prednisolone, and was further delayed after MPPT. Since the concentration of lactoferrin in the cells of these three groups of patients was similar, the delayed accumulation of lactoferrin in the plasma reflects delayed secretion. This is consistent with the inhibition of degranulation, as both involve fusion of the granules with the plasma membrane. ${ }^{21}$ Arthralgia is an important clinical feature in many of the 'autoimmune' type of diseases. MPPT has been shown to improve this symptom in SLE. ${ }^{8}$ It may do this by inhibiting the release of inflammatory mediators and toxic products from neutrophils ${ }^{23}$ and possibly other types of cells, such as mast cells. ${ }^{24}$

In conclusion, no obvious impairments of phagocyte function was found in patients with SLE who received small doses of prednisolone. The predisposition to infection in these patients may be due to abnormalities in the microvasculature, ${ }^{25}$ or abnormalities of other aspects of the immune system, that have not been investigated in this study. The impaired phagocyte functions demonstrated in the patients after pulse therapy with methylprednisolone could account for the increase in susceptibility to infection observed in patients receiving this form of treatment. ${ }^{26}$

We thank the Medical Research Council, Wellcome Trust, North East Thames Regional Health Authority, and University of Basrah, Iraq for financial support; Mr P. Martin for assistance with the operation of the Haemalog D Cell Counter; and Mrs J. Macfarlane for secretarial assistance. 


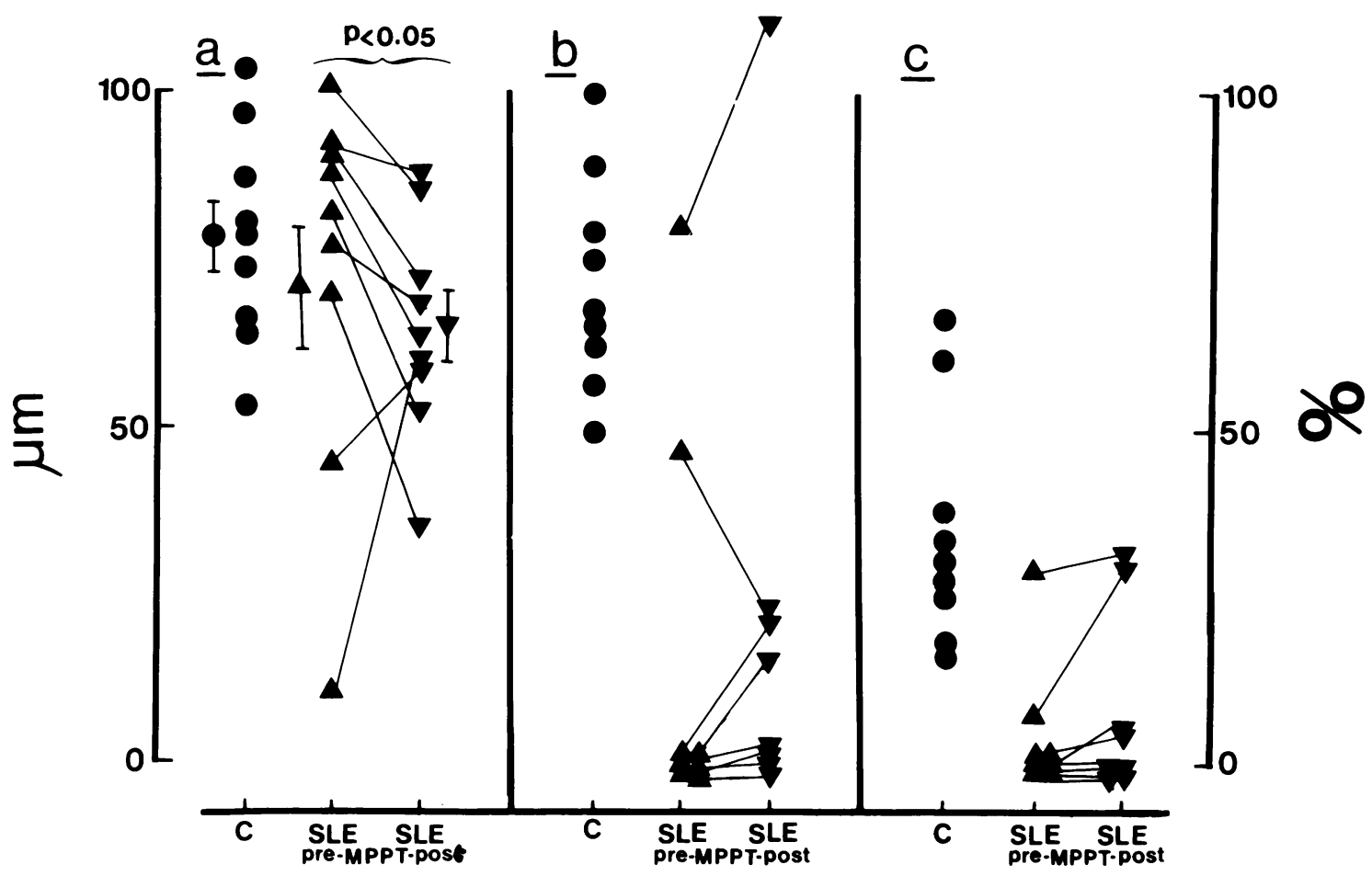

Fig. 6 Cell migration from skin windows in patients with SLE before $(\mathbf{\Delta})$ and after ( $\mathbf{\nabla})$ MPPT in comparison with healthy subjects (O). The distance moved from the skin abrasion into a Millipore membrane is shown for neutrophils (a) and monocytes in (b). The percentage of monocytes in the emigrating cells is shown in (c).

\section{References}

1 Staples P G, Gerding D N, Decker J L, Gordon R S. Incidence of infection in systemic lupus erythematosus. Arthritis Rheum 1974; 17: $1-10$.

2 Ginzler E, Diamond H, Kaplan D, Weiner M, Schlesinger M, Seleznick M. Computer analysis of factors influencing frequency of infection in systemic lupus erythematosus. Arthritis Rheum 1978; 21: 37-44.

3 Pillay V K G, Wilson D M, Ing T S, Kark R M. Fungus infection in steroid-treated systemic lupus erythematosus. JAMA 1968; 205: 261-5.

4 Urowitz M B, Bookman A A M, Koehler B E, Gordon D A, Smythe H A, Ogryzlo M A. The bimodal mortality pattern of systemic lupus erythematosus. Am J Med 1976; 60: 221-5.

5 Bell R R F, Briggs J D, Calman K C, et al. Reversal of acute clinical and experimental organ rejection using large doses of intravenous prednisolone. Lancet 1971; ii: 876-80.

6 Cathcart E S, Scheinberg M A, Idelson B A. Couser W G. Beneficial effects of methylprednisolone 'pulse' therapy in diffuse proliferative lupus nephritis. Lancet 1976; ii: 163-6.

7 Kimberly R P, Lockshin M D, Sherman R L, McDougal I S, Inman R D, Christian C L. High dose intravenous methylprednisolone pulse therapy in systemic lupus erythematosus. $A m \mathrm{~J}$ Med 1981; 70: 817-24.

8 Isenberg D A, Marrow W J W, Snaith J L. Methylprednisolone pulse therapy in the treatment of systemic lupus erythematosus. Ann Rheum Dis 1982; 41: 347-51.
9 Boghossian S H. Wright G. Segal A W. The kinetic measurement of phagocyte function in whole blood. J Immunol Methods 1983; 60: $125-40$.

10 Addison I E, Johnson B. Shaw M. A human skin window technique using micropore membranes. J Immunol Methods 1982: 54: 129-39.

11 Tan E M, Cohen A S, Fries J F. et al. The 1982 revised criteria for the classification of systemic lupus erythematosus. Arthritis Rheum 1982; 25: 1271-7.

12 Morrow W J W, Isenberg D A. Todd Pokropek A, Parry H F. Snaith M L. Useful laboratory measurements in the management of systemic lupus erythematosus. $Q J$ Med 1982; 51: 125-38.

13 Armitage P. Further analysis of straight-line data. Statistical methods in medical research. Oxford and Edinburgh: Blackwell. 1971: 269-301.

14 Nie H H, Hull C H, Jenkins J G. Steinbrenner K. Bend D H. Statistical package for the social sciences. 2nd ed. New York: McGraw-Hill, 1975.

15 Yam L T, Li C Y, Crosby W H. Cytochemical identification of monocytes and granulocytes. Am J Clin Pathol 1971; 55: 283-90.

16 Lentnek A L, Schreiber A D, MacGregor R R. The induction of augmented granulocyte adherence by inflammation. Mediation by a plasma factor. J Clin Invest 1976; 57: 1098-103.

17 Perez H D, Kimberly R P. Kaplan H B, Edelson H, Inman R D, Goldstein I M. Effect of high-dose methylprednisolone infusion on polymorphonuclear leukocyte function in patients 
with systemic lupus erythematosus. Arthritis Rheum 1981; 24: 641-7.

18 Gewurz H, Page A R, Pickering R L, Good R A. Complement activity and inflammatory neutrophil exudation in man. Studies in patients with glomerulonephritis. Essential hypocomplementemia and agammaglobulinemia. Int Arch Allergy 1967; 32: $64-90$.

19 Huber H, Holm G. Surface receptors of mononucler phagocytes: effect of immune complexes on in vitor function in human monocytes. In: van Furth $\mathrm{R}$, ed. Mononuclear phagocytes in immunity, infection and pathology. Oxford: Blackwell, 1975: 201-301.

20 Hällgren R, Hakansson L, Venge P. Kinetic studies of phagocytes. I. The serum independent particle uptake by PMN from patients with rheumatoid arthritis and systemic lupus erythematosus. Arthritis Rheum 1978; 21: 107-13.

21 Weissmann G, Thomas L. Studies on lysosomes. I. The effects of endotoxin, endotoxin tolerance and cortisone on the release of acid hydrolases from a granular fraction of rabbit liver. $J$ Exp Med 1962; 116: 433-50.

22 Bennett R M, Kokocinski T. Lactoferrin content of peripheral blood cells. Br J Haematol 1978; 39: 509-21.

23 Ignarro L J. Glucocorticosteroid inhibition of nonphagocytic discharge of lysosomal enzymes from human ncutrophils. Arthritis Rheum 1977; 20: 73-83.

24 Pipkorn U. Andersson P. Budesonide and nasal mucosal histamine content and anti-IgE induced histamine release. Allergy 1982; 37: 591-5.

25 Houck J C. Chemical messengers of the inflammatory process. Amsterdam: Biomedical Press, Elsevier/North Holland, 1979: 1.

26 Kauffman H M, Stromstad S A. Sampson D. Stawicki A T. Randomized seroid therapy of human kidney transplant rejection. Transplant Proc 1979; 11: 36-8.

\section{Book review}

Multiple Choice Questions in Rheumatology. By Ian D. Griffiths and P. Platt. Pp. 119. £3.95. Pitman: London, 1984.

This book forms part of a series in the medial specialties and subspecialties. The aims and method of use are clearly delineated in the foreword by the consulting editor, Dr John Anderson, and in the author's preface, which are both essential to the successful use of these MCQs. In particular their recommendation to follow up highlighted areas of ignorance together with a list of suitable texts for this purpose is eminently sensible. In addition useful short comments are provided with the answers to initiate the educational aspect of these questions.

Undergraduates will find some of the questions beyond their expected knowledge. It is unfortunate that an acceptable score for different groups has not been included-such as undergraduates $40-60 \%$, MRCP candidates $60-70 \%$, senior registrar $90-100 \%$, consultants classified information!

I found this book interesting, enjoyable, and instructive. Well worth recommending to those facing MCQ papers or who wish to identify blind spots worth eliminating.

C. J. EASTMOND 